Original Research Paper

\title{
Reassessment of Molecular Variation in Isolated Populations of Deschampsia cespitosa from Metal Contaminated Regions in Northern Ontario (Canada) after 17 Years of Potential Genetic Recombination
}

\author{
${ }^{1}$ Sabrina Rainville, ${ }^{1}$ Peter Beckett and ${ }^{1,2}$ Kabwe Nkongolo \\ ${ }^{I}$ Department of Biology, \\ ${ }^{2}$ Biomolecular Sciences Program, \\ Laurentian University, Sudbury, Ontario, Canada, P3E 2C6, Canada
}

\section{Article history}

Received: 26-04-2017

Revised: 09-06-2017

Accepted: 01-07-2017

Corresponding Author:

Kabwe Nkongolo

Department of Biology and

Biomolecular Sciences

Program, Laurentian

University, Sudbury, Ontario,

Canada, P3E 2C6, Canada

Email: knkongolo@laurentian.ca

\begin{abstract}
The effects of ore extraction and processing procedures in the Greater Sudbury and Cobalt regions have been long-lasting. The objective of this study is to determine the current level of genetic variation in Deschampsia cespitosa populations from metal contaminated and uncontaminated sites in samples collected in Northern Ontario in 2016 after 17 years of potential genetic recombination since the last study in 1999. D. cespitosa leaf samples collected from the City of Greater Sudbury (CGS), Cobalt and Little Current were analyzed using ISSR primers. The levels of genetic variation were moderate to high within targeted populations. There was no significant difference $(p \leq 0.05)$ in the overall percent of polymorphic loci in metal-uncontaminated site of Little Current (from $70 \%$ in 1999 to $77 \%$ in 2016) and in a Cobalt Cart Lake site (from $48 \%$ in 1999 to $55 \%$ in 2016). But a significant decrease in genetic variation was observed in CGS Wahnapitae site (from $72 \%$ in 1999 to $54 \%$ in 2016). On the other hand, a significant increase was observed in Cobalt Nipissing (from $46 \%$ in 1999 to $64 \%$ in 2016). The Kelly Lake site in the CGS with the lowest level of polymorphic loci $(42.5 \%)$ in 2016 was not surveyed in 1999. The degree of genetic relatedness among sites has increased since the populations are more genetically closely related than 17 years ago. No population-specific ISSR marker was identified. The clustering of Cobalt and Sudbury populations strengthens the earlier theory that Sudbury populations of $D$. cespitosa might be from the Cobalt region.
\end{abstract}

Keywords: Deschampsia cespitosa, Northern Ontario, Genetic Variation, Metal Contamination, ISSR Markers

\section{Introduction}

The effects of ore extraction and processing procedures on the aquatic and terrestrial ecosystems in the Greater Sudbury and Cobalt regions have been long-lasting. In Sudbury, the roasting and smelting of sulfur-rich pentlandite and niccoline ores reduced the soil $\mathrm{pH}$ through acidic precipitation and spread airborne metal particulates in the region (Amiro and Courtin, 1981; Dudka et al., 1995; Gratton et al., 2000; Nkongolo et al., 2013). The predominant ore was erythrite in the Cobalt region's operations with the environmental impact tied primarily to the deposition on the tailings that has contaminated the surrounding soils with metals (Percival et al., 2007; Adamowicz, 2014; Dumaresq, 1993). Changes in $\mathrm{pH}$ and elevated metal concentrations induce stress and limit plant growth, leading to erosion and the leaching of nutrients in the soils of the area (Winterhalder, 1996; Spiers et al., 2012; Nkongolo et al., 2013). While both regions have undertaken restoration efforts which include liming, seeding and capping, total levels of metals on-site are 
still high (Percival et al., 2007; Adamowicz, 2014; Nkongolo et al., 2013; 2016).

Selective pressures such as metal stress can cause potentially resistant species to adapt to these challenging conditions. Over time, a population can inadvertently eliminate other alleles from its gene pool. This loss of diversity can reduce its adaptation potential in the future (Mejnartowicz, 1983; Mengoni et al., 2001; Deng et al., 2007; Gervais and Nkongolo, 2011). It is therefore important to monitor the dynamics of genetic variability within and among plant populations. This will be useful in assessing the effects of potential stressors and the sustainability of reclaimed ecosystems.

ISSR is a reproducible nuclear marker that can be used when the sequence of the species being tested is not known (Nagaoka and Ogihara, 1997; Nkongolo et al., 2005 ; 2016), allowing one to fingerprint and differentiate closely related populations (Raina et al., 2001; Nkongolo et al., 2003; 2005). It can be used to assess genetic variability which can shift over generations.

Dechampsia cespitosa is a cosmopolitan grass and is found in damp habitats and has colonized disturbed microsites in Cobalt and Sudbury. Nkongolo et al. (2001) and Gervais and Nkongolo (2011) assessed genetic variation in $D$. cespitosa populations from Northern Ontario. They found a low level of polymorphism in $D$. cespitosa samples collected in 1999 from cobalt compared to samples from Sudbury. The highest level of polymorphic loci was found in samples from metal uncontaminated sites (Gervais and Nkongolo, 2011).

The objective of this study is to assess the current level of genetic variation in $D$. cespitosa populations from sites with different levels of metal contamination in Northern Ontario in 2016 after a further 17 years of potential genetic recombination.

\section{Materials and Methods}

\section{Sampling}

D. cespitosa leaves were sampled in five populations from Northern Ontario (Cobalt, Manitoulin Island and Sudbury). The sampling site locations are illustrated in Fig. 1. Two sites were in the town of Cobalt in the district of Timiskaming. They include Cobalt 1 and Cobalt 3, which refer to the Nipissing Tailings (CNT) and Cart Lake Tailings (CLT), respectively. The Sudbury area samples were from Wahnapitae (Wah) and Kelly Lake (KL) sites, while the uncontaminated control site was from Little Current (LC) on Manitoulin Island. With the exception of Kelly Lake, all the sites were surveyed in 1999. For each site, about $10 \%$ of the populations were collected. Leaf materials from each mature individual were wrapped in aluminum foil, flashfrozen and stored at $-20^{\circ} \mathrm{C}$ until DNA extraction.

\section{DNA Extraction}

Genomic DNA extraction was performed using the protocol previously described by Mehes et al. (2007). This protocol is a modified version of the procedure outlined in Doyle and Doyle (1987). The following changes were made: Addition of $1 \%$ Polyvinyl Pyrrolidone (PVP) and $2 \% \beta$-mercaptoethanol to the Cetyltriethylammonium Bromide (CTAB) buffer solution and two additional chloroform centrifugation steps of ten minutes each prior to the isopropanol spin and the removal of the RNAse step. The extracted DNA was then kept at $-20^{\circ} \mathrm{C}$ until further analysis.

DNA quantification was performed using the BioRadTM quantitation kit's fluorochrome Hoechst procedure (catalog \# 170-2480) described in Mehes et al. (2007).

\section{ISSR Analysis}

The five primers that were used in the analysis of the 1999 samples were selected for this ISSR analysis (Gervais and Nkongolo, 2011). They included ISSR 17898B, UBC818, UBC 827, UBC 835 and UBC 841 primers. PCR amplification was performed according to the procedure described in Mehes et al. (2007). The program was set to a hot start of $5 \mathrm{~min}$ at $95^{\circ} \mathrm{C}$ followed by $2 \mathrm{~min}$ at $85^{\circ} \mathrm{C}$ at which time the Taq solution was added. Overall, a total of 42 cycles of 1.5 $\min$ at $95^{\circ} \mathrm{C}, 2 \mathrm{~min}$ at $55^{\circ} \mathrm{C}$ and $1 \mathrm{~min}$ at $72^{\circ} \mathrm{C}$ were completed. A final extension of $7 \mathrm{~min}$ at $72^{\circ} \mathrm{C}$ completed the reaction. Samples were then removed from the thermocycler, cooled in ice then kept at $-20^{\circ} \mathrm{C}$ until further analysis.

Amplified DNA products were separated on a $2 \%$ agarose gel in 0.5 xTBE containing ethidium bromide as described in Mehes et al. (2007) and Gervais and Nkongolo (2011). The gel was documented with a BioRad ChemiDoc XRS system and the recorded data were analyzed using Image Lab (ver, 4.1) SoftwareTM.

The ISSR amplified bands were recorded as either absent (0) or present (1). The observed and expected number of alleles, Nei's gene diversity, Shannon's information index and the level of polymorphism were estimated using Popgene software version 1.32. Jaccard's similarity matrix with FreeTree version 0.1.9.50 was used to calculate genetic distances. A dendrogram was produced using the Jaccard similarity coefficients using TreeViewX, with patristic distance to scale branch lengths based on the neighbor-joining analysis from FreeTree version 0.1.9.50. 


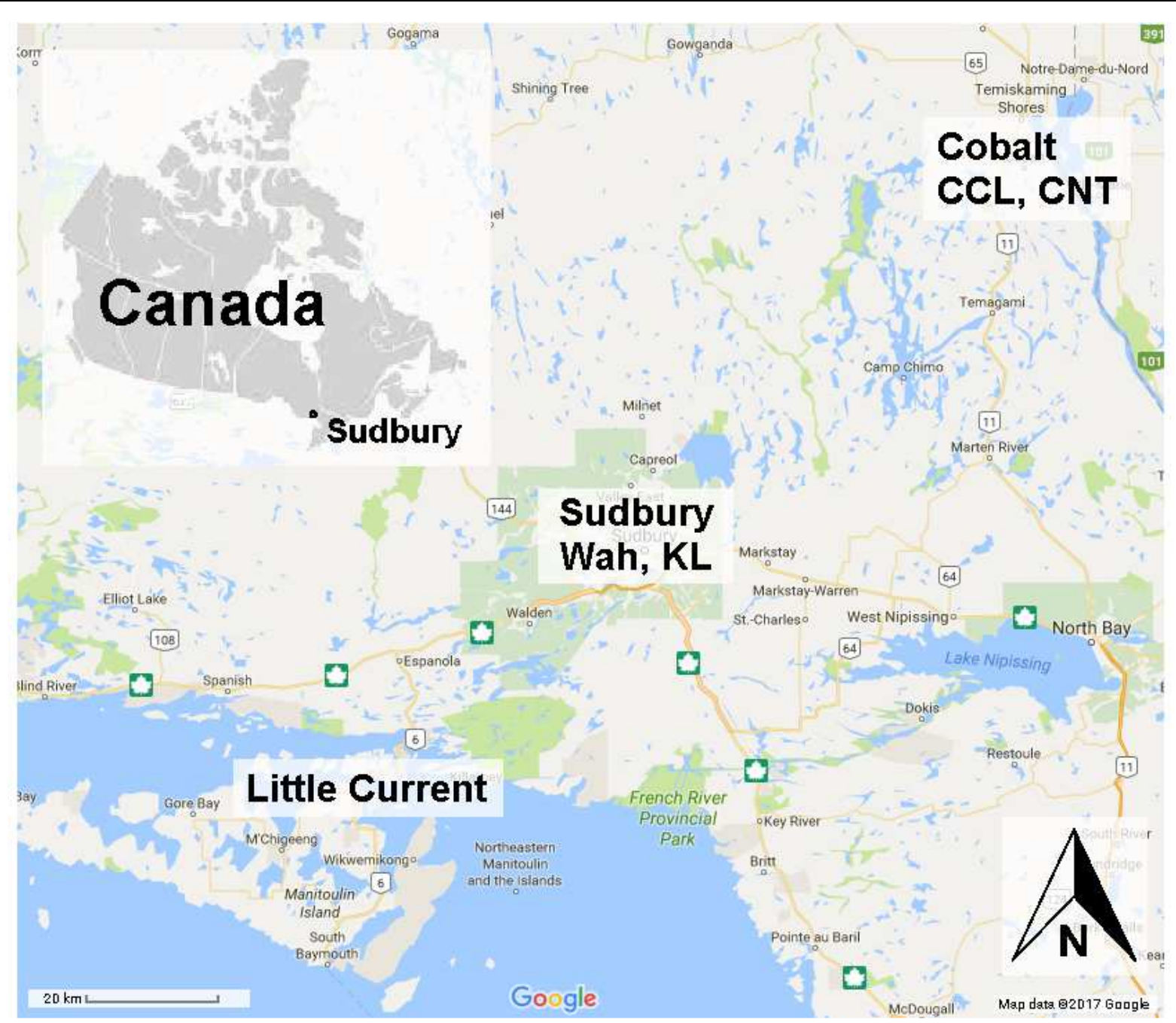

Fig. 1. Map showing sampling locations in Cobalt, Sudbury and Little Current regions. These sites included Cobalt Nipissing Tailings (CNT) and Cart Lake Tailings (CLT), Wahnapitae (Wah), Kelly Lake (KL) and Little Current (LC)

\section{Results}

\section{ISSR Analysis}

Detailed characteristics of the five selected primers used in this study are described in Table 1. Figure 2 depicts the amplified products generated with ISSR primer 841. Total number of scored bands ranged from 73 to 83 , with band sizes varying from 200 to $1700 \mathrm{bp}$.

Table 2 describes all the genetic parameters measured that include the observed number of alleles $(\mathrm{Na})$, the expected number of alleles ( $\mathrm{Ne}$ ), Nei's gene diversity (h), Shannon's information index (I) and the percentage of polymorphic loci $(\mathrm{P})$. The mean of total gene diversity (HT) value was 0.35 and the gene diversity between populations (HS) was 0.22 . The mean population differentiation (Gst) value was 0.37 and the estimated gene flow $(\mathrm{Nm})$ was found to be 0.86 . The mean of inter-population polymorphism was $98.8 \%$.
Within each population, the levels of genetic variation were moderate to high. In the present study, the percentage of polymorphic loci varied between 42.5\% (Kelly Lake) and $77.0 \%$ (Little Current). Specifically, the highest level of genetic variation was observed in samples from metal uncontaminated site (Little Current). The two metal contaminated sites from the CGS had a moderate level of genetic variation with the level of polymorphic loci being $42.5 \%$ for Kelly Lake and $54 \%$ for Wahnapitae site. Surprisingly, for Cobalt, the genetic variation was moderate in Cobalt Cart lake (55\%) compared to a high genetic variation (69\%) observed in samples collected in Cobalt Nipissing.

The observed number of alleles ranged from 1.42 (Kelly Lake) to 1.77 (Little Current) with a mean of 1.595. The lowest expected number of alleles was observed in Kelly Lake (1.28) and the highest in Little 
Current to (1.51) with a mean of 1.387. Nei's gene diversity followed the same trend ranging from 0.16 (Kelly Lake) to 0.28 (Little Current) with a mean of
0.22. Likewise, Shannon's information index varied between 0.23 (Kelly Lake) and 0.42 (Little Current) with a mean of 0.325 (Table 2).

Table 1. Primer nucleotide sequences used to amplify genomic DNA from five populations of Deschampsia cespitosa

\begin{tabular}{llll}
\hline Primer identification & Nucleotide sequence $\left(5^{\prime} \rightarrow 3^{\prime}\right)$ & Amplification & Fragment size range $(\mathrm{bp})$ \\
\hline ISSR 17898B & CACACACACACAGT & Good & $260-1200$ \\
UBC 818 & CACACACACACACACAG & Good & $250-1560$ \\
UBC 827 & ACACACACACACACACG & Good & $290-1330$ \\
UBC 835 & AGAGAGAGAGAGAGAGYC & Good & $200-1400$ \\
UBC 841 & GAAGGAGAGAGAGAGAYC & Good & $220-1700$ \\
\hline
\end{tabular}

Table 2. Genetic diversity values for five D. cespitosa populations from Northern Ontario based on ISSR data

\begin{tabular}{llllll}
\hline & $\mathrm{Na}$ & $\mathrm{Ne}$ & $\mathrm{h}$ & $\mathrm{I}$ & $\mathrm{P}$ \\
\hline Cobalt Nipissing (Tailing 1) & 1.6897 & 1.4108 & 0.2371 & 0.3543 & 68.97 \\
Cobalt Cart Lake (Tailing 3) & 1.5517 & 1.4112 & 0.2257 & 0.3270 & 55.17 \\
Wahnapitae & 1.5402 & 1.3249 & 0.1892 & 0.2826 & 54.02 \\
Kelly Lake & 1.4253 & 1.2830 & 0.1607 & 0.2366 & 42.53 \\
Little Current & 1.7701 & 1.5095 & 0.2878 & 0.4241 & 77.01 \\
\hline
\end{tabular}

Genetic diversity descriptive statistics. Na: Observed number of alleles; Ne: Expected number of alleles; h: Nei's gene diversity; I: Shannon's information index; P: Percentage of polymorphic loci

Table 3. Distance matrix generated using the neighbor-joining analysis using Deschampsia cespitosa ISSR data (FreeTree version $0.1 .9 .50)$

\begin{tabular}{llllll}
\hline & 1 & 2 & 3 & 4 & 5 \\
\hline 1 & 0.000 & 0.149 & 0.172 & 0.264 & 0.186 \\
2 & & 0.000 & 0.048 & 0.167 & 0.174 \\
3 & & 0.000 & 0.000 & 0.176 \\
4 & & & & 0.207 \\
5 & & & & 0.000 \\
\hline
\end{tabular}

1 represents $D$. cespitosaCobalt-1 population (Nipissing Tailings); 2 D. cespitosa Cobalt-3 population (Cart Lake); 3 D. cespitosa Wahnapitae population; 4 D. cespitosa Kelly Lake population; 5 D. cespitosa Little Current population.

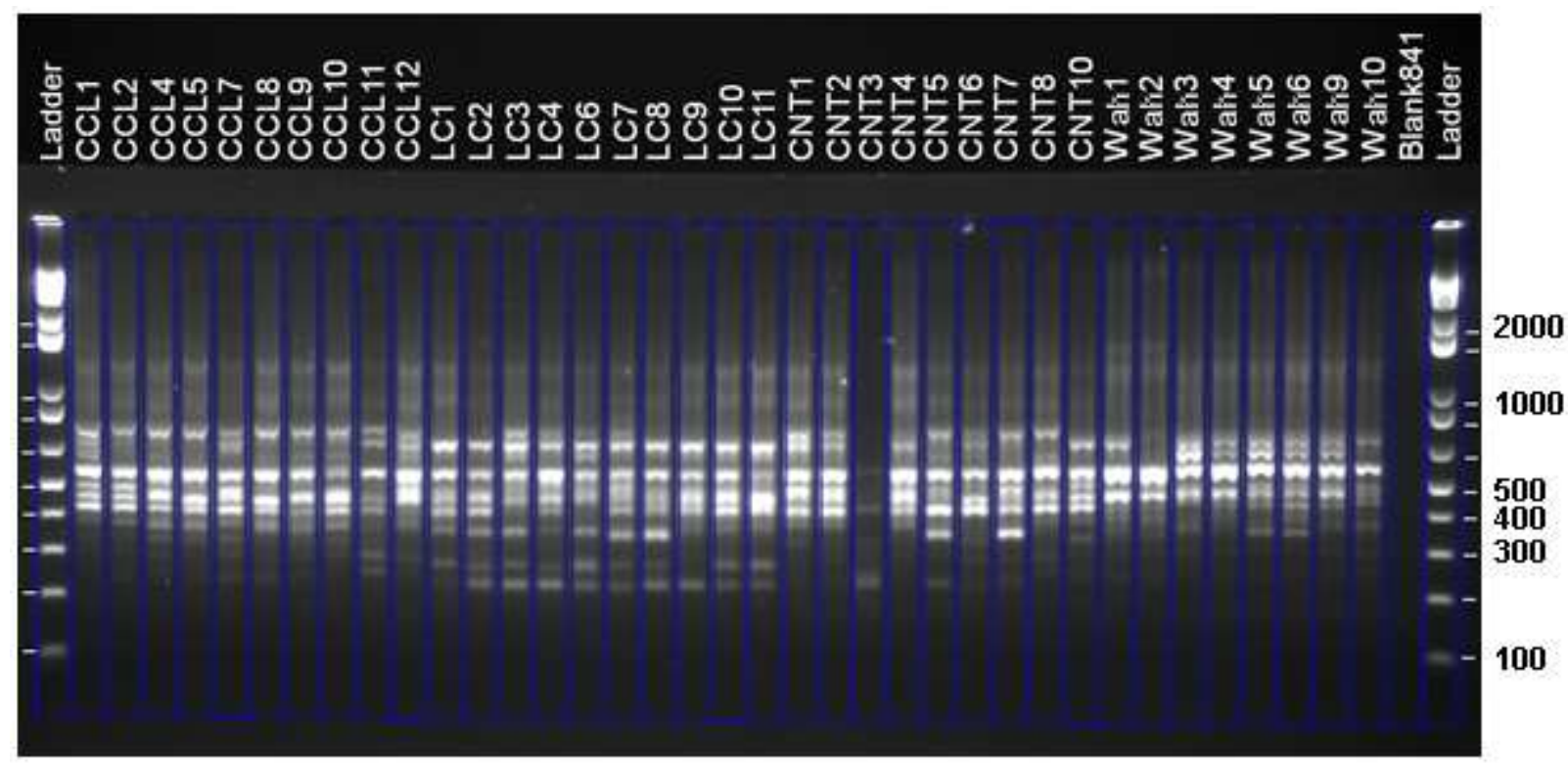

Fig. 2. ISSR amplification of $D$. cespitosa with primer UBC 841. The flanking lanes (1 and 40) contain $1 \mathrm{~Kb}+$ ladder, lanes 2 to 39 amplified products from samples from Cobalt 3 (Cart Lake -CCL), Little Current (LC), Cobalt 1 (Nipissing Tailings-CN) and Wahnapitae (Wah) 


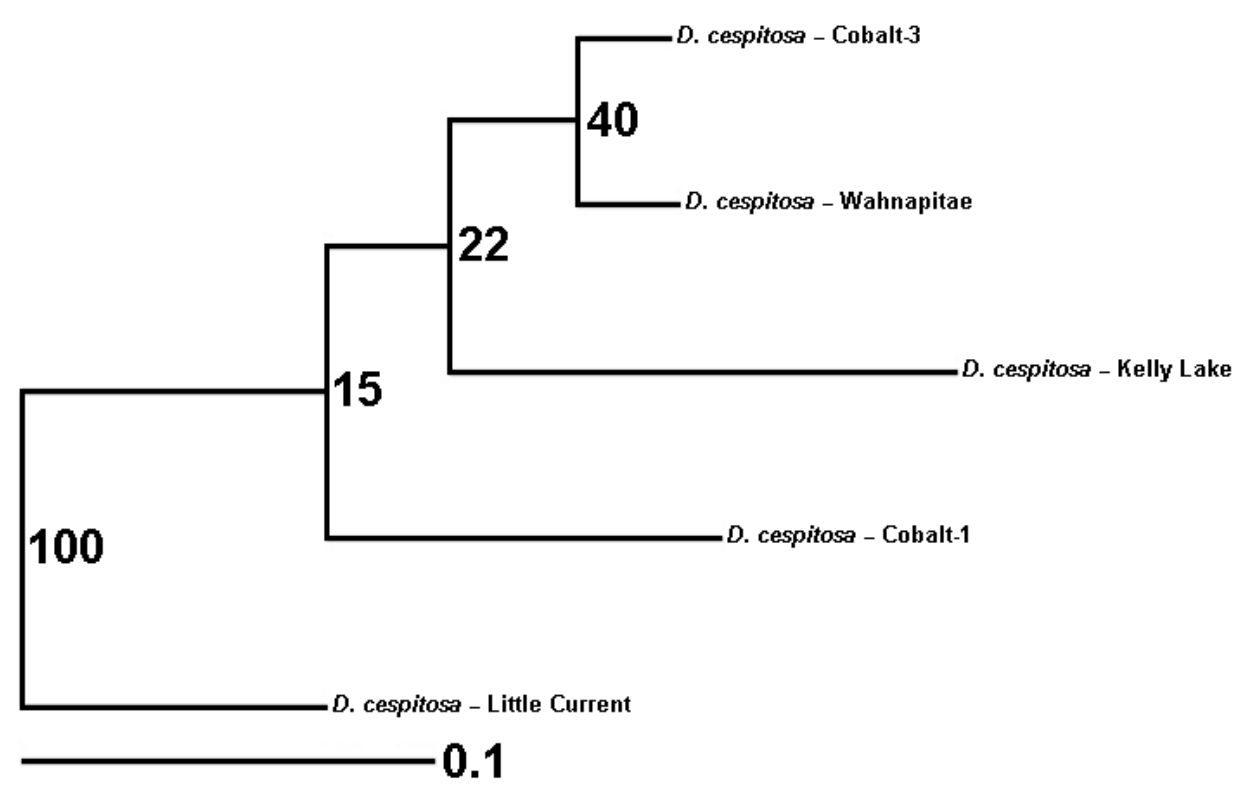

Fig. 3. Dendrogram of the genetic relationships between the five D. cespitosa populations from Northern Ontario using the Jaccard neighbor-joining similarity matrix from ISSR profiles. Branch lengths are to scale and show the patristic distance based on the neighbor-joining analysis. Cobalt 1 is Cobalt Cart lake tailing and Cobalt 3, is Cobalt Nipissing tailing.

Genetic distances among sites were estimated based on 0 (identical populations) to 1 (completely different populations) scale. Overall, all the five populations are genetically closely related since the genetic distance values vary between 0.048 and 0.264 (Table 3). The lowest genetic distance value (0.048) was observed between Cobalt-Cart and Wahnapitae suggesting that they are the most genetically related. The population clustering based on ISSR data was not associated with geographic distances. The dendogram generated shows that all the metal contaminated sites cluster together with the uncontaminated site (Little Current) being separate from the cluster with $100 \%$ degree of confidence (Fig. 3). No population diagnostic markers were found between metal contaminated and uncontaminated sites.

\section{Discussion}

Data related to metal content for the five targeted sites have been discussed in previous reports (Nkongolo et al., 2001). It has been well documented that nickel and copper are the main contaminants of soils in the Greater Sudbury Region including Wahnapitae and Kelly Lake areas while arsenic, cadmium, cobalt, copper, lead and zinc, are found in high levels in Cobalt sites. Little Current is among the least metalcontaminated and was used as reference for this study (Nkongolo et al., 2001).

It is expected that genetic variation will increase in plant populations challenged with novel environmental stressors (Service and Rose, 1985; Holloway et al., 1990).
If resistance to metal in an outcrossing and perennial species such as $D$. cespitosa is a quantitative trait, it is very likely that allelic frequency will be maintained over time (Von Frenckell-Insam and Hutchinson, 1993); MacNair, 1993). This is expected to result in a neutral genetic variation (Gervais and Nkongolo, 2011).

Resistant plants can develop if the toxic stress continues at a sublethal level for many generations (Nkongolo et al., 2001; Gervais and Nkongolo, 2011). A decrease in genetic variation can result from selection. Plants use different mechanisms to regulate intracellularly the levels of metal ions (Foy et al., 1978; Benavides et al., 2005). Development of metal-resistant plants can occur within one or two generations, in some populations (Wu et al., 1975). The main factors that play a key role in plant ability to sustain metal toxicity include the level of contamination and the amount of time it has been exposed to toxic levels.

In general, the appropriate timeframe for detecting meaningful changes in genetic variation will vary according to plant species and environmental conditions. The targeted sites in the CGS and the Cobalt region were mining areas well known for their ecosystem degradation caused by metal contamination and acid precipitations. The Cobalt tailings are more contaminated than the Sudbury soil. But the two sites selected in Sudbury (Kelly Lake and Wahnapitae wet lands) are the most metal-contaminated within the CGS. This has resulted in a significant decrease and a possible loss of some alleles that has lead ultimately to a lower level of polymorphic loci in $D$. cespitosa populations 
sampled in 1999 (Nkongolo et al., 2016). Changes in genetic variation at the population level caused by metal contamination in other species has been reported in many studies (van Straalen and Timmermans, 2002; Lopes et al., 2004). Mengoni et al. (2001) showed a significant decrease in genetic variation associated with Silene paradoxa populations growing in coppercontaminated soils.

In the present study, the levels of polymorphism were moderate to high within targeted populations from Sudbury, Cobalt and Little Current. When the polymorphism levels between the 1999 and the 2016 samples were compared, there was an insignificant change in the overall percent of polymorphic loci in metal-uncontaminated site of Little Current (from 70\% in 1999 to $77 \%$ in 2016) and in a Cobalt Cart Lake site (from $48 \%$ in 1999 to $55 \%$ in 2016). But a significant decrease in genetic variation was observed in Wahnapitae site (from $72 \%$ in 1999 to $54 \%$ in 2016). On the other hand, a significant increase was observed in Cobalt Nipissing (from $46 \%$ in 1999 to $64 \%$ in 2016). The Kelly Lake site with the lowest level of polymorphic loci of $42.5 \%$ in 2016 was not surveyed in 1999. The levels of observed number of alleles, Nei's gene diversity, Shannon's information index followed the same trend.

The increase in genetic variation in Cobalt Nipissing population is surprising. It might be due to new genetic recombination involving de novo or outside sources of genetic materials that did change the genetic profile of this population. Since $D$. cespitosa is an open pollinated species, pollens from other areas transported by wind could be involved in reshuffling the genetic makeup of this population. This scenario is unlikely considering the distance between the two sites. Since it is a short-lived species, it is expected that the samples collected are from at least three generations of genetic recombination. Hence de novo recombination without external sources might be the most acceptable explanation especially if the alleles in the population were not fixed. The contribution of seeds carried by birds and anthropogenic activities must also not be discounted. It is also possible that the population surveyed in 2016 from the Cobalt Nipissing tailing is a new population that may have colonized the site in the last decade. The sharp decrease of genetic variation in Wahnapitae site might be due to population changes. It is known that gene flow can counteract gene frequency changes in a population and imposes a limit on local adaptation (Lenormand, 2002). It is possible that population surveyed in 2016 in this site was composed of survivors of the 1999 population that was growing in soils with very high level of nickel leading to a decrease of genetic variation.

The degree of genetic relatedness between sites has increased since the populations are more closely related than 17 years ago. A significant change in genetic distance is in part caused by a high gene flow. But, in the present study, the gene flow was low $(<1)$. Usually gene flow between 1 and 0.5 , is weak but possibly effective for the transfer of favorable genes and values below 0.5 suggest that groups are almost or fully isolated (Wolf and Soltis, 1992; Lenormand, 2002). Indeed, the level of difference in genetic variation observed between the two Sudbury sites suggests that gene exchange between them is limited. The same phenomenon was observed for the two Cobalt sites. Analysis of samples collected in 1999 also revealed a low level of gene flow among the targeted populations (Gervais and Nkongolo, 2011). This low level of gene exchange can be ascribed to the geographic distances among the targeted populations. In fact, the closest sites are about $2 \mathrm{~km}$ away from each other and the most distant sites are $>300$ $\mathrm{km}$ apart. The clustering of Cobalt and Sudbury populations strengthens the earlier theory that Sudbury populations of $D$. cespitosa might be from the Cobalt region (Von Frenckell-Insam and Hutchinson, 1993; Gervais and Nkongolo, 2011).

\section{Conclusion}

The present study showed that in two of the populations studied, the level of genetic variation is unchanged after 17 years of genetic recombination, in one population, polymorphic loci degree has increased while in another population it has decreased. The metal uncontaminated site showed the highest level of genetic variation compared to metal contaminated sites. The targeted populations are more genetically closely related than they were 17 years ago. No population diagnostic ISSR marker was identified.

\section{Acknowledgement}

We would like to thank the Natural Sciences and Engineering Research Council of Canada (NSERC), VALE and Sudbury Integrated Nickel Operations (Glencore) for financial support.

\section{Author's Contributions}

Sabrina Rainville: Collected samples from the five targeted sites, conducted the ISSR analysis and processed the data.

Peter Beckett: Collected samples and conducted the ecological analysis of the sites.

Kabwe Nkongolo: Collected samples, monitored the experiments, reviewed the data and wrote the manuscript.

\section{Conflict of Interest}

The authors declare no conflict of interest 


\section{References}

Adamowicz, M., 2014. Exploring cobalt: The historic silver capital of Canada,

Amiro, B.D. and G.M. Courtin, 1981. Patterns of vegetation in the vicinity of an industrially disturbed ecosystem, Sudbury, Ontario. Can. J. Bot. 59: 1623-1639. DOI: 10.1139/b81-221

Benavides, M.P., S.M. Gallego and M.L. Tomaro, 2005. Cadmium toxicity in plants. Braz. J. Plant Physiol., 17: 21-34.

DOI: $10.1590 / \mathrm{S} 1677-04202005000100003$

Deng, J., B. Liao, M. Ye, D. Deng and C. Lan et al., 2007. The effects of heavy metal pollution on genetic diversity in zinc/cadmium hyperaccumulator Sedum alfredii populations. Plant Soil, 297: 83-92. DOI: $10.1007 /$ s11104-007-9322-5

Doyle, J.J. and J.L. Doyle, 1987. A rapid DNA isolation procedure for small quantities of fresh leaf tissue. Phytochem. Bull. 19: 11-15.

Dudka, S., R. Ponce-Hernandez and T.C. Hutchinson, 1995. Current level of total element concentrations in the surface layer of Sudbury's soils. Sci. Total Environ., 162: 161-171. DOI: $10.1016 / 0048-9697(95) 04447-9$

Dumaresq, C., 1993. The occurrence of arsenic and heavy metal contamination from natural and anthropogenic sources in the Cobalt area of Ontario. MSc. Thesis, Department of Earth Science, Carleton University, Ottawa, Ontario.

Foy, C.D., R.L. Chaney and M.C. White, 1978. The physiology of metal toxicity in plants. Annu. Rev. Plant Physiol., 29: 511-566.

DOI: 10.1146/annurev.pp.29.060178.002455

Von Frenckell-Insam, B.A.K. and T.C. Hutchinson, 1993. Occurrence of heavy metal tolerance and co-tolerance in Deschampsia cespitosa (L.) Beauv. from European and Canadian populations. New Phytol., 125: 555-564. DOI: $10.1111 /$ j.1469-8137.1993.tb03903.x

Gervais, S. and K. Nkongolo, 2011. Effect of metal contamination on the genetic diversity of Deschampsia cespitosa Populations from Northern Ontario: An application of ISSR and microsatellite markers. InTech.

Gratton, W.S., K.K. Nkongolo and G.A. Spiers, 2000. Heavy metal accumulation in soil and jack pine (Pinus banksiana) needles in Sudbury, Ontario, Canada. Bull. Environ. Contam. Toxicol., 64: 550-557. DOI: $10.1007 / \mathrm{s} 001280000038$

Holloway, G.J., S.R. Povey and R.M. Sibly, 1990. The effect of new environment on adapted genetic architecture. Heredity, 64: 323-330.

DOI: $10.1038 /$ hdy. 1990.40

Lenormand, T., 2002. Gene flow and the limits to natural selection. Trends Ecol. Evolut., 17: 183-189.

DOI: $10.1016 / \mathrm{S} 0169-5347(02) 02497-7$
Lopes, I., D.J. Baird and R. Ribeiro, 2004. Genetic determination of tolerance to lethal and sublethal copper concentrations in field populations of Daphnia longispina. Arch. Environ. Contam. Toxicol., 46: 43-51. DOI: $10.1007 / \mathrm{s} 00244-003-2143-5$

Macnair, M.R., 1993. The genetics of metal tolerance in vascular plants. New Phytol., 124: 541-559. DOI: 10.1111/j.1469-8137.1993.tb03846.x

Mehes, M.S., K.K. Nkongolo and P. Michael, 2007. Genetic analysis of Pinus strobus and Pinus monticola populations from Canada using ISSR and RAPD markers: Development of genome-specific SCAR markers. Plant Syst. Evolut., 267: 47-63. DOI: 10.1007/s00606-007-0534-1

Mejnartowicz, L., 1983. Changes in genetic structure of Scotch pine (Pinus sylvestris L.) population affected by industrial emission of fluoride and sulphur dioxide. Genet. Pol., 24: 41-50.

Mengoni, A., C. Barabesi, C. Gonnelli, F. Galardi and R. Gabbrielli et al., 2001. Genetic diversity of heavy metal-tolerant populations in Silene paradoxa L. (Caryophyllaceae): A chloroplast microsatellite analysis. Mol. Ecol., 10: 1909-1916. DOI: $10.1046 /$ j.0962-1083.2001.01336.x

Nagaoka, T. and Y. Ogihara, 1997. Applicability of inter-simple sequence repeat polymorphisms in wheat for use as DNA markers in comparison to RFLP and RAPD markers. Theor. Applied Genet., 94: 597-602. DOI: 10.1007/s001220050456

Nkongolo, K.K., A. Deck and P. Michael, 2001. Molecular and cytological analyses of Deschampsia cespitosa populations from Northern Ontario (Canada). Genome, 44: 818-825. DOI: $10.1139 / \mathrm{g} 01-063$

Nkongolo, K.K., L. Deverno and P. Michael, 2003. Genetic validation and characterization of RAPD markers differentiating black and red spruces: molecular certification of spruce trees and hybrids. Plant Syst. Evolit., 236: 151-163. DOI: $10.1007 / \mathrm{s} 00606-002-0236-7$

Nkongolo, K.K., P. Michael and T. Demers, 2005. Application of ISSR, RAPD and cytological markers to the certification of Picea mariana, P. glauca and $P$. engelmannii trees and their putative hybrids. Genome, 48: 302-311. DOI: 10.1139/g04-118

Nkongolo, K.K., P. Michael, G. Theriault, R. Narendrula and P. Castilloux et al., 2016. Assessing biological impacts of land reclamation in a mining region in Canada: Effects of dolomitic lime applications on forest ecosystems and microbial phospholipid fatty acid signatures. Water Air Soil Pollut., 227: 104-104. DOI: 10.1007/s11270-016-2803-5

Nkongolo, K.K., G. Spiers, P. Beckett, R. Narendrula and G. Theriault et al., 2013. Long-term effects of liming on soil chemistry in stable and eroded upland areas in a mining region. Water Air Soil Pollut., 224: 1618-1618. DOI: 10.1007/s11270-013-1618-x 
Percival, J.P., YT.J. Kwong, C.G. Dumaresq and F.A. Michel, 2007. Distribution of As, Ni and Co in tailings and surface waters in the cobalt area, Ontario. Proceedings of the Mining and the Environment IV Conference, Oct. 19-27, Sudbury, Ontario, Canada.

Raina, S.N., V. Rani, T. Kojima and Y. Ogihara, 2001. RAPD and ISSR fingerprints as useful genetic markers for analyis of genetic diversity, varietal identification and phylogenetic relationships in peanut (Arachis hypogaea) cultivars and wild species. Genome, 44: 763-763.

Service, P.M. and M.R. Rose, 1985. Genetic covariation among life-history components: The effect of novel environments. Evolution, 39: 943-945. DOI: $10.2307 / 2408694$

Spiers, G.A., C.D. Wren and D. McLaughlin, 2012. Distribution of chemicals of concern in the study area. W. C, ed. Maralte, Leiden, Netherlands.
Van Straalen, N.M. and M.J.T.N. Timmermans, 2002. Genetic variation in toxicant-stressed populations: An evaluation of the "Genetic Erosion" hypothesis. Hum. Ecol. Risk Assess., 8: 983-1002. DOI: $10.1080 / 1080-700291905783$

Winterhalder, K., 1996. Environmental degradation and rehabilitation of the landscape around Sudbury, a major mining and smelting area. Environ. Rev., 4: 185-224. DOI: 10.1139/a96-011

Wolf, P.G. and P.S. Soltis, 1992. Estimates of gene flow among populations, geographic races and species in the Ipomopsis aggregata complex. Genetics, 130: 639-647.

Wu, L., A.D. Bradshaw and D.A. Thurman, 1975. The potential for evolution of heavy metal tolerance in plants. Heredity, 34: 165-187. DOI: $10.1038 /$ hdy.1975.21 